\title{
APPLICATION OF CONSTRUCTIVISM IN JAPANESE TEACHING ACCORDING TO EXPERIENTIAL LEARNING FOR UNIVERSITY STUDENTS
}

\author{
NGUYEN THITINH ${ }^{1}$, NGUYEN THIUT SAU ${ }^{2}$, NGUYEN THI THANHHUYEN ${ }^{3}$, \\ HUYNH TAN HOI ${ }^{4} \&$ KIEU THI THU CHUNG ${ }^{5}$ \\ ${ }^{1,2,3}$ University of Education, Thai Nguyen University, Vietnam \\ ${ }^{4}$ FPT University, Vietnam \\ ${ }^{5}$ FPT University, Vietnam
}

\begin{abstract}
Constructivist theory asserts that knowledge must be created by the learners themselves, sought from the treasure of human knowledge and learning content with the support of teachers and learning materials, learning environment. Teaching Japanese based on experience based on constructivist theory prevails in the goal of forming the ability to listen, speak, read, write in Japanese and Japanese cultural competence for university students. In order to achieve the above goal, Japanese-language lecturers must be in-depth of expertise, good at methods and technologies.
\end{abstract}

KEYWORDS: Constructivism,Learners, Experience-Oriented Teaching \& Teachers

Received: Jun 09, 2020; Accepted: Jun 29, 2020; Published: Jul 25, 2020; Paper Id.: IJMPERDJUN2020462

\section{INTRODUCTION}

In recent years, in the trend of international and regional integration, and in particular, the strong development of cooperation relations between Vietnam and Japan in all aspects, Japanese research and teaching in Vietnam is interested in developing in the direction of expanding and intensive with the goal of forming the ability to listen, speak, read and write in Japanese for learners, helping students have the opportunity to adapt to career and career development. In addition, the study of Japanese language helps to improve the knowledge of Japanese language of the learners, which also forms the development of their ability to explain the culture, the relationship between people - language - culture of people [1]. The understanding of the mother tongue, the national culture also becomes more profound. Through the process of analyzing and comparing the language and culture of other countries, learners see the problem in a more diverse way, thinking becomes more open to social issues.

\section{CONTENT OF RESEARCH}

\section{Educational Philosophy, Learning Objectives in Japanese Language Training for Students}

Educational philosophy is a guideline for all Japanese teaching and learning activities in education - training students at universities, educational philosophy decides the content, methods of teaching and learning Japanese.

The focus of the orientation in Japanese language training in the current period is the formation and development of students' ability to connect with multilingual and multicultural societies; dialogue capacity, social capacity to solve common problems of the two countries and humanity; The ability to survive in a society with more and more change. With the goal: "learn to know, learn to do, learn to live together, learn to assert yourself" 
(UNESCO Organization - Educational, Scientific and Cultural Organization of the United Nations initiated).

In order to accomplish the above-mentioned training goals, the teaching and learning of Japanese language must be conducted based on the theory of constructivism [1].

\section{Applying Constructivist Theory in Teaching Japanese Language towards Experience for University Students}

The core ideology of constructivist theories is that knowledge comes through the subject of perception, structuring itself into its internal system, subjective knowledge. In other words, knowledge must be created by the learners themselves, sought from the treasure of human knowledge and learning content with the support of teachers and learning materials, learning environment [2].

Constructivist theory emphasizes the role of cognitive subject in the interpretation and constructivism of knowledge, constructivist theory belongs to subject theory, decided by cognitive subject, therefore, before the content of learning, each learner is competent tectonic forces and achieve different results (Figure 1).

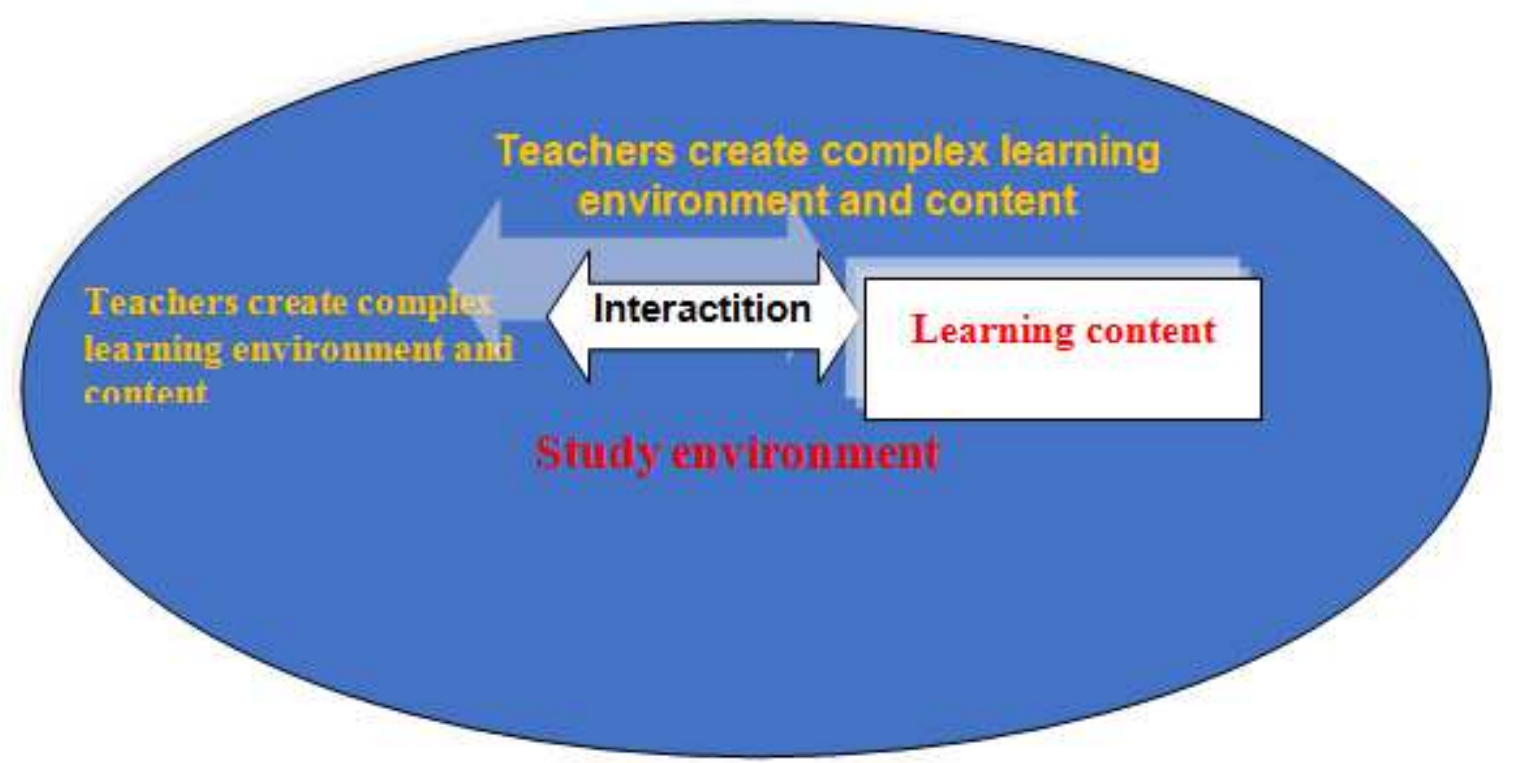

Figure 1: Constructivist theory in teaching

Lecturers need to organize the interaction between learners and learning objects, to help learners build new information into their thinking structures, self-adjust the thinking process to create new knowledge that learning is not only a discovery but also an explanation, a new structure of knowledge, helping learners grasp the nature of using knowledge as a tool to create new knowledge.

Applying constructivist theory in teaching Japanese language to university students who need to use experiential learning models and methods, organization of experiential teaching for students to develop learning environment effectively create an interaction between lecturers and students and learning content materials, thereby forming and developing Japanese language and cultural competence for students [3].

Teaching experience is a personal process in direct contact with the learning environment, things, communication phenomena, culture in Japanese, applying Japanese language and cultural experience to observe, interaction, perception of things, events, phenomena that are taking place in reality, thereby discovering the nature of things, phenomena or forming the development of Japanese language ability, cultural ability and so on. 
David Kolb argues that learning is a process in which knowledge is created through the conversion of experience [4].Kolb's experiential learning model consists of 4 stages in a closed circle [1]. According to Kolb, studying Japanese for university students requires study space and study space as a framework for understanding between students' learning and the environment (Figure 2). Therefore, the experience is an appropriate environment and space for teaching Japanese to help students develop their linguistic and cultural competencies, etc.

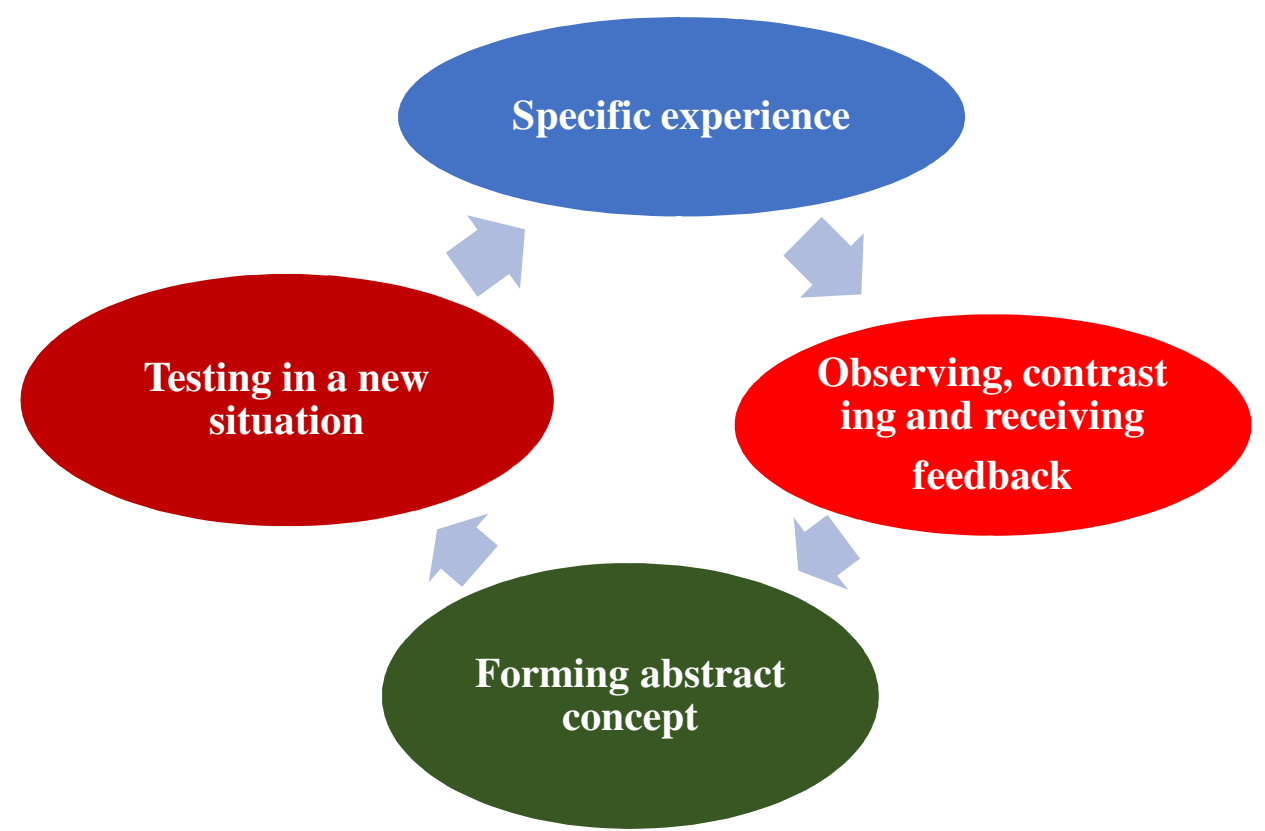

Figure 2: Four stages of constructivist theory

In order to apply the above requirements, Japanese language instructors need to perform the following tasks well.

Developing Japanese teaching environment through innovation of methods and organization of Japanese language teaching in the direction of experience, creating interaction between lecturers and students and students; students with an academic, realistic, or hypothetical environment [5].

Constantly sticking to students' knowledge and experience in the learning process, creating motivation, creating an environment for students to use Japanese knowledge and experience as a tool to develop their linguistic skills and cultural competence in the learning environment created by lecturers and students.

Design learning content topics associated with students' future real-life issues to practice and develop listening, speaking, reading, writing and Japanese speaking skills and competencies culture, etc. Teachers can, for example, design and organize topics on the impact of the US-China trade war on global financial and monetary markets or the topic: Japanese bilateral cooperation with Vietnam on culture and tourism; or the fight against Covid-19 pandemic in Japan in 2020 , etc. With the above topics, lecturers can take a lot of articles, analytical videos of experts in international newspapers and television to document to organize learning situations for students. By using these materials, both creating an interest in the content as this is a hot issue, and helping students gain listening and speaking skills, acquire financial and economic knowledge and especially access to many newly updated derivative words that are not in the dictionary or syllabus [6].

With theoretical and practical lessons, lecturers can design learning topics at businesses, organize students to directly contact Japanese experts and workers to implement learning projects. Lecturers base on the content of learning, 
practice, design learning projects at the enterprise, assign tasks to the student group to perform and evaluate through student product reports and student performance [7]. Through learning projects, students can practice listening, speaking, reading and writing skills in Japanese and have a better understanding of Japanese culture, thereby perfecting their linguistic and cultural competence.

Lecturers need to formulate and develop Japanese language learning methods for students, especially self-study methods and methods of interacting with others to study effectively [6]. In order to formulate and develop Japanese learning methods for students, lecturers need to teach students to clearly identify the purpose and motivation for learning; how to study, how to access online resources, on social networks, in which special attention is paid to the formation of selfstudy methods for students through social networks due to the current rate The use of smart devices and internet of Vietnamese youth is currently at a high level. In addition to giving advice to each individual student, there is a method of self-study but when learning Japanese students need techniques to learn vocabulary, grammar and listening, speaking, reading and writing skills; Training students to guess words in specific contexts associated with the situation; Developing a Japanese learning environment for students through diverse and diverse practices, working in pairs, medium and large groups, practical experiences in production, and a culture of tourism through small screens etc. In addition, teachers can also organize activities; games using Japanese language and culture, helping students take the initiative in learning through game experience, students practice skills including listening, speaking, reading and writing skills to improve the linguistic competence and understand more about the country, culture and people of the rising country. As the organizer, instructor, lecturers will be the observers, coordinators, and managers of learning activities, student play is the catalyst to create the atmosphere of the classroom motivated, excited and comfortable to stimulate students to actively participate in learning [8].

Lecturers should actively use information technology, social networks, achievements of the Industrial Revolution 4.0 in Japanese language teaching, and bilateral cultural and economic achievements between Vietnam and Japan. These are useful learning content for students. The use of technology, the mode of supporting modern technology with direct interaction, will support not only students to learn quickly and easily, but also the teachers will not put much pressure on lesson plans [9].

Lecturers need to develop the development of students' self-study skills through E-learning environment: Receive the exploitation of learning materials, receive learning tasks, and participate in the exchange forum; pay tests and assignments online. In addition, lecturers can use the connecting school model to teach Japanese to students through connecting with classes in Japan [10]. To achieve this goal, lecturers must be good at Japanese and technology, exploit and use technology as tools and organizational forms to teach Japanese effectively. For example, when discussing a job-related issue in Japan through live streaming with a Japanese expert, university lecturer or any other citizen (possibly an online friend of lecturers or students) to discuss it directly, it is both more vivid and more realistic.

\section{CONCLUSIONS}

Studying Japanese for university students is a process of creating new knowledge for students under the role of organization and guidance of university lecturers, understanding the capacity and capital of existing knowledge and experience of each student, creating a diverse interactive learning environment to help students experience the skills of listening, speaking, reading, writing, analyzing and comparing Japanese cultural values is essential for each lecture in teaching Japanese at university. In parallel with the development of tectonic learning environment for students based on 
their knowledge and experience, lecturers need to develop and develop Japanese self-studying students in a diverse environment and learn through classes. Through social networking, television and learning through E-learning environment, students can experience to create new knowledge and skills by themselves.

\section{ETHICAL CLEARANCE}

The authors ensure the quality and integrity of the research. By writing this research paper, the authorsall contributed the work together. Professor Nguyen ThiTinh, Nguyen ThiUt Sau (Ph.D), Nguyen Thi Thanh Huyen (Ph.D) gave the ideas, wrote the paper, then other authors completed the paper.

\section{ACKNOWLEDGEMENT}

We would like to send our warm thanks to our university as well as the advice from our colleagues in order to complete the paper.

\section{CONFLICT OF INTEREST}

There is no conflict of interest in the paper.

\section{SOURCE OF FUNDING}

The authors would like to send warm thanks to the workplace where they are working for.

\section{REFERENCES}

1. Huang, H. M. (2002). Toward constructivism for adult learners in online learning environments. British journal of educational technology, 33(1), 27-37.

2. Jonassen, D., Davidson, M., Collins, M., Campbell, J., \& Haag, B. B. (1995). Constructivism and computer-mediated communication in distance education. American journal of distance education, 9(2), 7-26.

3. Tan, H. H. (2019). The Applications of Artificial Intelligence and the Abilities of Supporting in Learning Japanese Language. In Proceedings of the 2019 2nd International Conference on Computational Intelligence and Intelligent Systems (pp. 156160).

4. Oluikpe, E., and N. Nwodo. "Nigerian English teachers' awareness of the basic tenets of EIL and implications for teacher education." International Journal of Linguistics and Literature 3.3 (2014): 9-22.

5. Kolb, A. Y., \& Kolb, D. A. (2005). Learning styles and learning spaces: Enhancing experiential learning in higher education. Academy of management learning \& education, 4(2), 193-212.

6. Hoi, H. T. (2019). Using Social Networks for English Teaching and Learning. In Proceedings of the 2019 2nd Artificial Intelligence and Cloud Computing Conference (pp. 173-177).

7. Kolb, A. Y., \& Kolb, D. A. (2006). Learning styles and learning spaces: A review of the multidisciplinary application of experiential learning theory in higher education. In Learning styles and learning: A key to meeting the accountability demands in education (pp. 45-91). Nova Science Publishers New York.

8. MANNA, RAKESH, and JAYANTA METE. "Secondary teacher education system in India with special reference to West Bengal." International Journal of Humanities and Social Sciences 5.3 (2016): 97-111.

9. Kageto, M., \& Sato, S. (2010). Rethinking the university learning environment: How to enrich students' education through a constructivist learning environment. International Journal for Educational Media and Technology, 4(1), 67-78. 
10. Abid Ali, WasfiDhahir, and SamaherSabri Hameed. "A Study on Factors Inducing Stress Among Students in Nursing College." International Journal of Human Resources Management (IJHRM) ISSN (P) (2018): 2319-4936.

11. Iba, T., \&Munakata, K. (2019). Pattern language and the future of education in light of constructivist learning theories, part 1: consideration with generic epistemology by Jean Piaget. In Proceedings of the 24th European Conference on Pattern Languages of Programs (pp. 1-7).

12. Siddiqui, Kalim. "Higher education in the era of globalisation." International Journal of Humanities and Social Sciences 3.2 (2014): 9-32.

13. Tafor, P., Geier, S., Ogunmuyiwa, E. N., \&Addo-Tenkorang, R. (2016). Higher education involving students: A literature research in constructivism, connectivism, and experiential learning perspective.

14. Scheer, A., Noweski, C., \&Meinel, C. (2012). Transforming constructivist learning into action: Design thinking in education. Design and Technology Education: An International Journal, 17(3). 